\title{
Oligarquias em sociedades de socorros mútuos (1854-1940)
}

\section{Adhemar Lourenço da Silva Jr.}

Resumo: O artigo trata das "oligarquias" nas sociedades de socorros mútuos. Comparando-se essas associações do Rio Grande do Sul com outras, ou em outros lugares, ou em outros momentos, pode-se ver que é difícil defini-las como "democráticas". Isto será demonstrado por meio da análise da liderança, dos procedimentos eleitorais e das assembleias gerais.

Palavras-chave: sociedades de socorros mútuos, democracia, oligarquia

Abstract: The article deals with "oligarchies" in mutual benefit societies. Comparing these friendly societies from Rio Grande do Sul with other associations, or other places, or other times, one can see that it is difficult to set that they are "democratic" associations. This is going to be proved by the analysis of the leadership, electoral procedures, and general assemblies.

Keywords: mutual benefit societies, democracy, oligarchy

O tema do associativismo como "escola de democracia" é clássico no pensamento social e foi retomado por meio do estudo de Robert Putnam. O autor incorpora, parcialmente, os argumentos desenvolvidos por Tocqueville na "Democracia na América" acerca dos critérios por meio dos quais se atribui a uma associação voluntária o caráter pedagógico condizente com a construção de democracias. Segundo o primeiro autor, as associações horizontais, internamente, democráticas e com poucas barreiras à entrada de novos membros, seriam lugares mais propícios à conformação de indivíduos com "interesses [próprios] bem compreendidos". O "interesse bem compreendido", agora segundo Tocqueville, seria uma virtude moral capaz de exceder a atomização individual resultante da modernização social. Como o elemento central da "democracia americana" (como, de resto, do liberalismo em geral) seria a capacidade do indivíduo compreender-se como autônomo e dotado de interesses passíveis de satisfação nos mercados (econômico,

\footnotetext{
* Professor da graduação e do mestrado em História da UFPel. Este artigo trabalha, novamente, alguns elementos trazidos em outros textos, cf., sobretudo, SILVA Jr., Adhemar Lourenço da. Democracia e dirigentes nas sociedades de socorros mútuos. In: TARGA, Luiz Roberto, HERRLEIN Jr., Ronaldo, MERTZ, Marli Marlene. 2as. Jornadas de História Regional Comparada Anais [recurso eletrônico]. Porto Alegre: PUCRS, 2005, incorporando outros dados possíveis por meio de Bolsa de Iniciação Científica FAPERGS para o projeto O associativismo no Rio Grande do Sul, 1920-1950. E-mail: adhemarj@ufpel.edu.br
} 
político, erótico, etc.), haveria uma tendência de atomização, caso não se considerassem como válidas (ou resultantes de transformações também resultantes da ação individual) as regras pautadas para o funcionamento desses mercados. Caso não houvesse "virtudes morais" capazes de nos fazer respeitar normas, apenas os interesses seriam válidos, voltando-se a um modelo de "guerra de todos contra todos", segundo o modelo hobbesiano. Tocqueville e Putnam destacam a sociabilidade nas associações voluntárias como requisito para a constituição do "interesse bem compreendido", e Putnam, explicitamente, menciona as sociedades de socorros mútuos na Itália como atendendo a tais requisitos. Também Marcel van der Linden, embora não atente, especificamente, ao debate das virtudes morais, destaca a sociabilidade interna e a gestão democrática como importantes elementos para a caracterização das mutuais ${ }^{1}$.

O presente texto ignora, em boa medida, tanto as críticas implícitas, as explícitas ou as possíveis críticas à posição de Putnam ${ }^{2}$, quanto as ressalvas à definição de mutuais trazida por Linden $^{3}$. Além disso, desconsidera mesmo o contexto

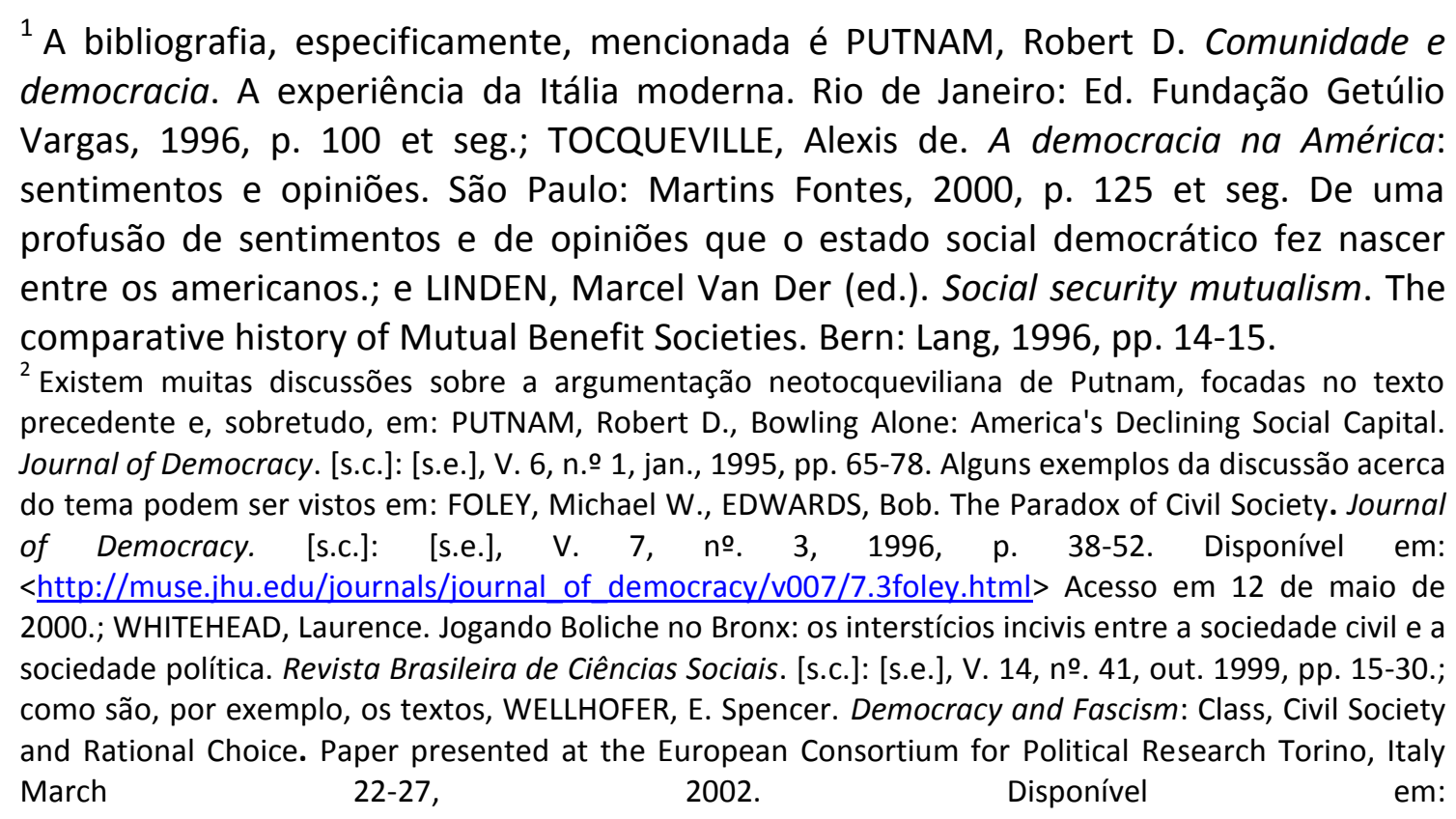
$<$ http://www.essex.ac.uk/ecpr/events/jointsessions/paperarchive/turin/ws7/>. Acesso em 14 de outubro de 2002.; SKOCPOL, Theda, GANZ, Marshall, MUNSON, Ziad. A Nation of Organizers: The Institutional Origins of Civic Voluntarism in the United States. American Political Science Review. [s.c.]: [s.e.], sep., 2000.; KAUFMAN, Jason. Three views of associationalism in 19th-century America: an empirical examination. The American Journal of Sociology. Chicago: [s.e.], V. 104, no. 5, pp. 1296-1345, mar., 1999.

${ }^{3}$ NEKBY, Lena. Pure Vs. Mutual Sick Insurance Societies. Evidence from Swedish Historical Data. Stockholm, 10 sep. 2001. Disponível em: <http://www.ne.su.se/paper/wp01 10.pdf>. Acesso em 1 de jul. de 2004. Também disponível em Journal of Risk and Insurance. V. 71, no. 1. pp. 115-134; 2001; ALBORN, Timothy. Senses of belonging: the politics of working-class insurance in Britain, 18801914. Journal of Modern History. [s.c.]: [s.e.], V. 73, pp. 561-602, sep., 2001. 
intelectual em que escreve Tocqueville, tal como tratado por Hoffmann ${ }^{4}$. Essa ignorância permite, quando muito, indicar alguns elementos para uma teoria mais geral da associação voluntária. Contudo, o objetivo deste artigo é outro: estudar os procedimentos internos de certo tipo de associação voluntária - as sociedades de socorros mútuos - tal como os encontrados no Rio Grande do Sul (Brasil), entre 1854 e 1940, de forma a iniciar a modelação de variáveis que relacionam às esferas social e política.

As entidades definidas por Putnam, como já dito, teriam poucas barreiras à entrada, mas a natureza dessas barreiras não é claramente balizada pelo autor e, por outro lado, seriam frequentes em sociedades de socorros mútuos. Linden ${ }^{5}$ sublinha a necessidade de pesquisa, mesmo para entidades com funcionamento democrático, sobre os critérios de exclusão que abrangiam desde fatores de risco para a securitização (como doenças pré-existentes), até as causadas por concepções de honra e de sociabilidade, como a exclusão de mulheres. Acredita-se que a tensão entre as exclusões à entrada e à gestão democrática seria parcialmente resolvida, não só metodologicamente, mas também empiricamente, no Rio Grande do Sul, por meio da distinção entre os membros com direitos sociais e aqueles também com direitos políticos. São, basicamente, dois os direitos políticos vetados a certos membros: o de participar em assembleias gerais e o de integrar as diretorias. Os critérios de exclusão política (e, às vezes, também social) tendem a ser os seguintes: idade, sexo, atividade socioprofissional e etnia, combinados ou não. Se a exclusão por idade e por sexo pode estar vinculada à conformação do conjunto de socorros - o chefe masculino de família, ao se associar, torna também beneficiários de socorros esposa, filhos e demais membros da família considerados incapazes de proverem seu sustento. A filiação destes seria redundante, apenas aumentando os custos de reprodução familiar -, as exclusões por atividade socioprofissional e por etnia integram o desejo dos membros de institucionalizarem e de exibirem publicamente componentes de orgulho. A atividade socioprofissional e a etnia parecem ser os critérios mais frequentes de fechamento, uma vez que foram constatados não só no Rio Grande do Sul, como também em outros universos empíricos americanos ${ }^{6}$.

\footnotetext{
${ }^{4}$ HOFFMANN, Stefan-Ludwig. Democracy and Associations in the Long Nineteenth Century: Toward a Transnational Perspective. The Journal of Modern History. [s.c.]: [s.e.], V. 75, pp. 269-299, june 2003.

${ }^{5}$ Op. cit., p. 27.

${ }^{6}$ LUCA, Tânia Regina de. O sonho do futuro assegurado. São Paulo: Contexto, 1990.; BATALHA, Claudio H. M. Sociedades de trabalhadores no Rio de Janeiro do século XIX: algumas reflexões em torno da formação da classe operária. Cadernos AEL: Sociedades operárias e mutualismo. Campinas: UNICAMP, Vol. 6, nso. 10-11, pp. 41-68, [s.m.], 1999.; GREZ TOSO, Sérgio. The mutual benefit movement in Chile from its origins to the present time, 1853-1992. In: LINDEN, Marcel Van Der (ed.). Social security mutualism. The comparative history of Mutual Benefit Societies. Bern: Lang, 1996, pp. 627-654.;
} 
Há, no entanto, um hiato entre a associação para a satisfação de interesses materiais, na forma de uma securitização da capacidade de reprodução social - tal como ocorre em sociedades de socorros mútuos -, e a promoção de interesses espirituais - tais como se poderia supor nos estudos interessados na "identidade" dos grupos sociais (seja qual for a acepção do termo) ${ }^{7}$. Esse hiato tem efeitos na forma assumida pela associação voluntária, porque "Where efficiency, variety and many options are important, bigger is usually better. But where relationships are important [...] smaller is often more likely to be beautiful" ${ }^{8}$. Devido à diferente natureza dos interesses, seria possível tipificar as sociedades de socorros mútuos entre aquelas nas quais predominam um ou outro desses interesses, tal como faz Alborn ${ }^{9}$. Segundo o autor, com essa tipificação, as mutuais que privilegiam os interesses materiais manteriam um tipo de estratégia de representação de interesses mais próximo das companhias comerciais de seguros do que as demais associações voluntárias, uma vez que estariam pautadas pela lógica do mercado. Aquilo que, contudo, a tipificação não resolve é a necessidade de manter, na maior parte das sociedades de socorros mútuos, os dois tipos de interesses: caso faltem os interesses materiais, a associação resume-se a um grupo institucionalizado de sociabilidade. Caso faltem os espirituais, os critérios de fechamento perdem muito de seu sentido e a opção do interessado em se securitizar seria apenas pautada pelas condições de comprar o serviço no mercado, e não por quaisquer demandas de "identidade".

Há um paradoxo na aplicação da modelagem de Putnam ao estudo das sociedades de socorros mútuos. Tal como Tocqueville, Putnam interessa-se pela relação de virtudes morais com regimes políticos, mas o próprio Tocqueville é mais cuidadoso na incorporação dos interesses materiais nessa relação, porque distingue o vínculo a partidos políticos do vínculo às demais associações voluntárias, quando não

DEVOTO, Fernando J. Las sociedades italianas de ayuda mutua en Buenos Aires y Santa Fe. Ideas y problemas. Studi Emigrazione. Roma: anno XXI, no. 75, pp. 320-342, set., 1984,; MUNCK, Ronaldo. Mutual benefit societies in Argentina: workers, nationality, social security and trade unionism. Journal of Latin American Studies. Cambridge: [s.e.], no. 30, pp. 573-590, [s.m.], 1998. e GARCÍA-BRYCE, Iñigo. Politics by peaceful means: artisan mutual aid societies in mid-nineteenth-century Lima, 1860-1879. The Americas. [s.c.]: [s.e.], Vol. 59, no. 3, pp. 235-345, jan., 2003.

7 Discutimos, recentemente, o problema da "identidade", manifestando-nos contrário a seu uso analítico em: SILVA Jr., Adhemar Lourenço da. A associação de trabalhadores difere daquela dos demais seres humanos? Paper apresentado no I Seminário Internacional Mundos do Trabalho: Histórias do Trabalho no Sul Global - V Jornada Nacional de História do Trabalho. Disponível em: <http://www.labhstc.ufsc.br/globalsouth/Sessao\%204.zip>. Nessa ocasião, ainda não havíamos lido o texto de BRUBAKER, Rogers, COOPER, Frederick. Beyond “identity". Theory and Society. [s.c.]: [s.e.], Vol. 29, no. 1, pp. 1-47, fev., 2000.

${ }^{8}$ BRINT, Steven. Gemeinschaft revisited: a critique and reconstruction of the Community concept. Sociological Theory. [s.c.]. [s.e.], Vol. 19, no. 1, mar., 2001, p. 4.

${ }^{9}$ Op. cit. 
haveria riscos monetários no vínculo político ${ }^{10}$. Esse risco é real, em sociedades de socorros mútuos, e a promoção de interesses espirituais pelas associações tenta converter valores de um tipo em outro. Quanto vale um enterro? Ele, certamente, tem um valor em dinheiro, mas as mutuais, com frequência, não o pagavam só com dinheiro, mas também com o prestígio de estandartes e da exibição pública de respeitabilidade do falecido. Na linguagem contábil, os pagamentos são "créditos de caixa", porque se define o caixa como sempre devedor. Os sinistros materiais ocorridos aos sócios levam as mutuais a pagarem o que julgam dever ao sócio e o valor dessa dívida é, comumente, pago com bens materiais e espirituais. O paradoxo aludido é que os fechamentos - que seriam, tendencialmente, menos democráticos na acepção de Putnam - são requisitos para a incorporação de interesses materiais e espirituais às associações voluntárias, porque a promoção de virtudes, em meio aos associados - e não sua simples enunciação -, depende de gradações do acesso aos bens e aos socorros, por estabelecer uma única escala para medir, de um lado, a virtude do sócio e, de outro, o sentido do bem ou do recurso oferecido. Definir que alguns têm acesso ao que outros não têm é atribuir valor a isso que só disponível a quem de direito. $\mathrm{A}$ questão é saber que coisas são essas e qual é o seu valor relativo. Quando a mutual é aberta, a única coisa à qual se pode atribuir valor é ao socorro, porque a gradação de virtudes e de bens oferecidos só é capaz de distinguir os que são associados dos que não são. Paradoxalmente, o mesmo ocorre quando a mutual é totalmente fechada, isto é, quando os critérios de fechamento não estabelecem quaisquer gradações no acesso aos direitos. Em qualquer um dos dois casos, a única diferença é a que existe entre os que estão dentro e os que estão fora. Nessas condições, ou não existe interesse espiritual algum na entidade ou ela desenvolve um espírito de seita que torna improvável sua persistência ao longo do tempo: o fechamento total levaria à incapacidade de prestar socorros quando do envelhecimento dos sócios ou à incapacidade de renovar os quadros de dirigentes, limitando a entidade a uma única geração.

Três elementos ajudam a construir escalas de valores que combinam o material e o espiritual. O primeiro deles é a existência de uma retórica de moralidade que defina os valores assumidos pela mutual. Chamá-la de "retórica" não é esvaziar seu conteúdo, mas pôr em relevo a necessidade de serem produzidos discursos persuasivos que atribuam à satisfação de interesses materiais o caráter de realização de interesses espirituais. Embora Tocqueville não utilize o termo, sua argumentação

\footnotetext{
${ }^{10}$ HOFFMANN, Stefan-Ludwig. Democracy and... op. cit., p. 272. e TOCQUEVILLE, Alexis de. $A$ democracia... op. cit., pp. 142-143.
} 
destaca o "interesse bem compreendido" como uma "doutrina [...] que transparece em todos os discursos; encontramo-la na boca do pobre como na boca do rico", caracterização que, embora não se limite à condição de uso da palavra, atenta o suficiente para essa dimensão textual. A retórica a que nos referimos envolve a capacidade de transcender as matérias concretas de deliberação por matérias abstratas (passando da quæstio finita à quæstio infinita), em discursos de qualquer gênero (judicial, deliberativo ou demonstrativo) ${ }^{11}$.

Exemplificamos com alguns casos provenientes da Sociedade de Beneficência Porto-Alegrense, mutual com fechamento étnico (só brasileiros do sexo masculino tinham direitos políticos) e classista (só alguns tipos de trabalhadores poderiam filiarse com todos os direitos políticos). Em 3 de março de 1859, um sócio propôs, na reunião de diretoria, que se investigasse a conduta de João Martins Bastos, devido ao comportamento "irregular e escandaloso". Alguns meses depois, na assembleia geral, a comissão deu seu parecer, no qual afirmava que o comportamento do sócio era uma falta passível de punição. Acontecia que Bastos era casado "com uma virtuosa senhora, e [vivia] amancebado com outra mulher". No debate da assembleia geral, vários oradores condenaram a conduta de Bastos, que se defendeu, invocando o testemunho de sua esposa. Em sua alocução, desculpando-se por sua "falta de inteligência", disse que ia a outra mulher a negócios, em uma interação que só podemos imaginar, pois era um "negócio melindroso". Depois de debates, procedeu-se à votação de sua expulsão, proposta que foi aprovada. Passando à segunda discussão do tema, um sócio usa uma metáfora interessante:

[...] reconhecendo a existência de qualquer mal, não segue o sistema do médico que corta a parte doente, antes pelo contrário [,] entende que se deve aplicar o necessário remédio [e] opina que o sócio Bastos não seja eliminado da Sociedade, pois que para correção do mesmo julga suficiente a discussão pública que tem havido a seu respeito [...]

${ }^{11}$ A citação encontra-se em Ibidem, p. 148. Para as definições de retórica, cf. LAUSBERG, Heinrich. Elementos de retórica literária. 3a ed. Lisboa: Fundação Calouste Gulbenkian, 1982. Não somos os primeiros a destacar a retórica em mutuais, uma vez que outro autor já o fez: cf. GLENN, Brian J. Fraternal rhetoric and the development of the U.S. Welfare State. Studies in American Political Development. [s.c.]: [s.e.], Vol., 15, (Fall 2001), pp. 220-233.; Idem. Postmodernism: the basis of insurance. Risk Management and Insurance Review. [s.c.]: [s.e.], Vol. 6, no. 2, pp. 131-143, [s.m.], 2003.; Idem. The shifting rhetoric of insurance denial. Law \& Society Review. Vol. 34, no. 3, pp. 779-808, [s.m.], 2000. 
Um outro orador também falou no mesmo sentido e o próprio acusado tomou a palavra pedindo "a indulgência da assembléia" e prometeu não mais se desviar "da senda dos seus deveres". Outros sócios corroboram o pedido, até que se solicitou a retirada do requerimento de expulsão, que foi aprovado. Cerca de seis meses depois, um outro requerimento foi encaminhado à reunião de diretoria, acerca de Amaro Francisco dos Santos, "que feriu gravemente sua mulher". Em menos de um mês, o tema foi submetido à assembleia geral. O debate não foi longo, embora alguns sócios, possivelmente amigos do acusado, pediram para não votar. O presidente afirmou que, para não votar, era necessário que eles se retirassem da assembleia, o que fizeram. Nesse segundo caso, não houve outra discussão, porque o sócio foi sumariamente expulso em 2 de fevereiro de $1860^{12}$. Ambos sócios tinham amigos nas assembleias que avaliariam o abuso da condição masculina, mas apenas Bastos cometera uma falha que não se opunha a um valor importante em qualquer sociedade de socorros mútuos. Ao se amancebar com uma mulher, invocando sua esposa como testemunha a seu favor, é provável que Bastos sustentasse e/ou protegesse ambas, ao passo que Amaro, tendo agredido sua esposa, não poderia ser mantido na posição de sócio também responsável pela gestão dos recursos necessários à proteção social de outros. Em outros termos, ambos tiveram uma conduta moral condenável e ambos foram condenados. Enquanto Bastos teve como punição ser vergonhado em uma sessão da assembleia geral - uma punição que tem efeitos espirituais, mas não materiais -, Amaro não poderia ser mantido como um igual entre aqueles que tinha, por responsabilidade, que proteger. Seria esse mesmo tipo de discussão, sobre as concepções de masculinidade, que transpareceria na necessidade da avaliação dos motivos das "riñas" dos sócios da Sociedad Española de Porto Alegre ou da Union Française de Pelotas: o conflito físico entre homens pode ser motivado pela agressividade inadequada à condição de protetor, ou não, e, por isso, caso a caso seria avaliado na escala de virtudes ${ }^{13}$.

O argumento para defender Bastos aplica à quæstio finita de deliberação sobre sua punição a quæstio infinita sobre a necessidade de aplicação de remédios e, não, a amputação do órgão doente. Já a utilidade de determinada medida (típica do gênero deliberativo) aparece, também, logo no começo do livro de atas da Sociedade de

\footnotetext{
12 LIVRO de atas das sessões da Sociedade de Beneficência Porto-Alegrense, 1856-1860, (Arquivos Particulares, cód. 01, Lata 54v - AHRS) fls. 64-93. É interessante constatar que os dois tipos de conduta também eram punidas pela Adam and Eve Society, na Irlanda, cf. CAMPBELL, John. Friendly societies in Ireland (1800-1980). In: LINDEN, Marcel Van Der (ed.). Social security... op. cit., pp.74-75.

${ }^{13}$ Extrato da ata da sessão da diretoria de 10 de setembro de 1917, livro n. 5, apud VARGAS, Iolanda Guimarães. História da Sociedade Espanhola de Socorros Mútuos de Porto Alegre. Porto Alegre: Programa de pós-graduação em história da cultura PUCRS, (Dissertação, mestrado em história), 1979, p. 198.; [ESTATUTOS da Union Française]. Requerimentos - Diversos, 1884 (AHRS, maço 214).
} 
Beneficência Porto-Alegrense, quando um sócio apresentou um requerimento para que:

[...] cada um sócio tenha uma cópia dos estatutos e do regimento interno, bem assim uma lista nominal de cada um sócio e do que vivem [...], requerendo [ainda] que para as sessões sejam escolhidos efetivamente as $1^{\text {as }}$ [sic] horas da noite do dia determinado, que os sócios, sem forçarem suas posses se apresentem decentemente para corroborar a força moral da nossa assembléia. Outrossim que seja expressamente proibido o fumar na sala das sessões; depois de bem discutido, foi aprovado nas duas sessões [de debate]. ${ }^{14}$

A decência no trajar não foi incorporada aos estatutos dessa entidade, mas aparece nos da União Caixeiral Jaguarense e, de resto, é facilmente identificável em fotografias das diretorias. A estreita relação entre o bem trajar e a exibição pública da entidade por meio de estandartes, de sedes, de símbolos e de adornos é mediada pela concepção de que se pode despender recursos em algo além da satisfação de interesses materiais, porque a gestão desses recursos permite gastar no que seria considerado supérfluo. Exibir-se publicamente de modo respeitável, "decente", só é considerado supérfluo quando são considerados apenas os interesses materiais dos associados, e não, seus interesses espirituais ${ }^{15}$. O gênero demonstrativo, por seu turno, está diretamente associado a esses momentos de exibição pública, ainda que não seja a eles restrito. Festas, solenidades e rituais são elementos retóricos que consolidam a união de interesses materiais e espirituais, como também são as narrativas exemplares que, às vezes, aparecem em relatórios. O relatório da Sociedade Portuguesa de Beneficência, em Rio Grande, datado de 1890, aborda o caso de um rico comerciante que se havia associado "mais por ato de beneficência que por necessidade", mas que, vendo-se arruinado, teve que recorrer ao "papel inútil, o diploma que havia recebido de sócio da nossa Benemérita sociedade [...]". Já o relatório da 24 de Maio, de Porto Alegre, elogia, em 1914, um sócio que recebeu diárias por doença, tendo em vista o atestado médico que o impedia de trabalhar, mas, quando um atestado divergente permitiu-lhe trabalhar, a narrativa exemplar

\footnotetext{
${ }^{14}$ Sessão de 18 mar. 1857. Livro de atas das sessões da Sociedade de Beneficência Porto-Alegrense, 1856-1860, op. cit., fl. 16.

${ }^{15}$ ESTATUTOS da União Caixeiral Jaguarense. Jaguarão: Officinas d'A Situação, 1909, art. $2^{\circ}$, § $4^{\circ}$ (BRG). ALBORN, op. cit., p. 573; SWIENCICKI, Mark A. Consuming brotherhood: men's culture, style and recreation as consumer culture, 1880-1930. Journal of Social History. [s.c.]: [s.e.], Vol. 31, [s.m.], 1998.
} 
destaca a honestidade e, por assim dizer, o "espírito público" desse associado, que se prontificou a devolver à mutual aquilo que havia recebido ${ }^{16}$.

Em todos os casos, não há como dizer que não havia interesses espirituais envolvidos. Mas, para os pesquisadores de hoje, a ausência desses discursos não aportaria evidências suficientes de outra coisa do que não o atendimento a interesses materiais. Nosso argumento depende da existência desses discursos e queremos crer que o público a quem foram dirigidos também precisavam deles para transcender a percepção de que sua associação voluntária atendia apenas a interesses materiais. Na falta desses discursos, a opção por uma ou outra mutual, ou uma companhia privada de seguros, apenas dependeria de sua capacidade de oferecer serviços. Quando a mutual tem um jornal, quando publica seus relatórios, além das questões administrativas tratadas, os atos retóricos de ligação dos interesses materiais com os espirituais assumem tal importância que chega a haver a proibição de detalhamento dos interesses materiais, como ocorre com o de nomes de_sócios, para livrá-los do opróbrio. Assim, só sobram os números gerais da entidade, que trazem os socorros de forma impessoal, e as narrativas exemplares ${ }^{17}$.

Quem produzia os discursos que eram capazes de fazer a conversão e a reconversão entre benefícios materiais e espirituais eram os grupos dirigentes das mutuais. Sua oligarquização é o segundo elemento a permitir a reconversão de um interesse em outro. Era bastante comum, no Rio Grande do Sul, tal como também ocorria na Catalunha, a prescrição de que o eleito para o cargo não poderia recusá-lo ${ }^{18}$. Isso pode ser interpretado como atendendo a interesses espirituais e materiais. Atenderia a interesses espirituais, quando consolidava a escala de valores da entidade, que atribuía, cada vez mais, deveres a quem tem mais virtudes. Recusar o cargo de dirigente conferido pelos iguais era ofensivo, porque considerava esses iguais como incapazes de discernimento de virtudes. A interpretação que faz a medida atender a interesses materiais é, provavelmente, mais verossímil: pouca gente tinha vontade de ser dirigente. Vejamos alguns casos de recusas interessantes (aceitas ou não), porque podem revelar quais os critérios que permitiam alguém a se esquivar da honraria (e das tarefas daí decorrentes). A primeira coisa a fazer é verificar se eventuais recusas

\footnotetext{
${ }^{16}$ RELATÓRIO da Sociedade Portuguesa de Beneficência na cidade do Rio Grande do Sul. Rio Grande: Typ. do Diário, 1890, p. 13 (BRG); RELATÓRIO do Club Beneficente 24 de Maio apresentado pelo presidente José de Carvalho em 5 de agosto de 1914, ao empossar a nova Diretoria. Julho de 1913 a Junho de 1914. Porto Alegre: Livraria Americana, 1914, p. 19-20 (IHGRGS).

${ }^{17}$ O Operário. Florianópolis, 2 mar. 1901, p. 1 - BPESC.

${ }^{18}$ RALLE, Michel. A função da proteção mutualista na construção de uma identidade operária na Espanha (1870-1910). Cadernos AEL: Sociedades operárias e mutualismo. Campinas: UNICAMP, Vol. 6, nso. 10-11, pp. 13-38, [s.m.], 1999, p. 23.
} 
não provêm de uma forma ritualizada de aceitação da honraria. Alguns exemplos indicam que não é assim.

O dever de ocupar cargos não era apenas uma declaração de princípios, mas um procedimento levado muito a sério na Sociedade de Beneficência Porto-Alegrense. Quando da eleição da diretoria, em 25 de março de 1858, um sócio protestou contra a "cabala" para que o fizessem vice-presidente, anunciando que renunciaria e que os eleitos para os cargos de $1^{\circ}$ secretário e de tesoureiros também pediram dispensa. 0 único dispensado o foi por motivos de saúde, tal como também ocorreria na eleição de 14 de abril de 1867. Outro caso de dispensa foi o de um membro que não queria assumir a tesouraria, em 15 de junho de 1871, porque, a despeito de seu trabalho anterior em prol da Porto-Alegrense, "agora desejavam dar-lhe demissão do cargo de tesoureiro por desconfiança do seu caráter, e que desejavam fazer o mesmo que fizeram com os srs. [...] e que para que não chegasse a esse ponto tinha a honra de mandar um requerimento pedindo a sua demissão". Tal como em outros casos, sua renúncia também foi rejeitada.

Já no Clube Caixeiral de Porto Alegre, um sócio publicou uma declaração no jornal, na qual declarou que não queria assumir cargo na mutual porque em "breve contrair[ia] matrimônio"19 ${ }^{19}$ o que parecia ser um motivo razoável. O outro exemplo não é, precisamente, de uma renúncia, mas do debate acerca da reforma dos estatutos da Sociedade Portuguesa de Beneficência, em Rio Grande, em 19 de junho de 1881. Nesse caso, um sócio manifestou-se contrário ao quorum de cinco membros para reuniões de diretoria, quando esta era composta por vinte integrantes. No debate que se seguiu, um dos membros da diretoria falou das "dificuldades que sempre existem para reunir maior número de membros" e outro relatou "que algumas vezes se viu na contingência de convidar e pedir pessoalmente aos membros da Diretoria transacta, de que fez parte, para comparecerem às sessões anunciadas". O interessante dos argumentos não é apenas o seu teor, mas o fato de que quem os enunciou não haviam sido escolhidos para altos cargos da diretoria da entidade (presidente, secretário, tesoureiro), pois eram o administrador do hospital e o procurador. $^{20}$

Tanto o secretário Sociedade de Beneficência Porto-Alegrense quanto os diretores da Sociedade Portuguesa de Beneficência, em Rio Grande, estavam

\footnotetext{
${ }^{19}$ O Athleta, 4 jun. 1885, p. 4.

${ }^{20}$ Sessões de 25 mar. 1858, 14 abr. 1867 e 15 jun. 1871. LIVROS de atas das sessões da Sociedade de Beneficência Porto-Alegrense, 1856-1860 (fl. 37) e 1867-1873 (fls. 2 e 85), (Arquivos Particulares, cód. 01 e 02, Lata 54v - AHRS).; O Athleta. Porto Alegre, 4 jun. 1885, p. 4 (MCSHJC). e Sociedade Portuguesa de Beneficência. Sessão de assembléia geral. Rio Grande, 19 jun. 1881. Anexo a: Sociedade Portuguesa de Beneficência. Requerimentos - Diversos, 1881, Maço 198 (AHRS).
} 
insatisfeitos com os cargos que ocupavam, mas houve casos em que os dirigentes queriam permanecer nos postos em que estavam. Os estatutos de mutuais variam sobre a permissão ou não da reeleição dos dirigentes e, quando o permitem, ela ocorre e é destacada como sintoma de eficiência e/ou de legitimidade. Na diretoria de 1908-1909, da caixa de Socorros Marquês do Pombal, em Pelotas, o presidente, o vicepresidente e o $1^{\circ}$ secretário foram reeleitos. Em 1909, também foram reeleitos, na Sociedade União Operária, de Rio Grande, o presidente, o $2^{\circ}$ secretário, o procurador, quase $25 \%$ dos conselheiros e o $1^{\circ}$ Secretário aparece com a indicação de que foi "eleito pelo décimo ano [consecutivo]" . Na União Operária, de Pelotas, a eleição de 1914 para nove membros da diretoria reelegeu o presidente, o vice-presidente, o $1^{\circ}$ secretário e o $2^{\circ}$ tesoureiro, sendo que o $1^{\circ}$ tesoureiro iniciaria o seu quarto mandato consecutivo. O fenômeno não é exclusivo do Rio Grande do Sul, quando se verifica que, na Grã-Bretanha, as mutuais locais eram dirigidas por um self-perpetuating comitee. Isso é algo o suficiente comum. Um outro trabalho já inventariou, em uma entidade do Recife, seis nomes ocupando quinze postos ao longo de três gestões ${ }^{21}$.

Mesmo quando a reeleição não é permitida, é possível que as mesmas pessoas ocupem cargos diferentes. Há, inclusive, estatutos que definiam apenas a eleição de um grupo de pessoas, que deveriam distribuir os cargos entre si, como aconteceu, em 1861, na Esperança Marítima, de Rio Grande, e na Sociedade Portuguesa de Beneficência, em Porto Alegre, nos estatutos de 1908 e de 1930. Esse é um fator relevante para avaliar o quanto são, realmente, democráticas as sociedades de socorros mútuos, uma vez que uma baixa renovação de diretorias indicaria um monopólio por parte de grupos e a impossibilidade de dissensos ou, pelo menos, a inexistência de mecanismos que permitam a livre discussão interna.

Adiante tratamos da existência desses mecanismos, mas, talvez, antes, fosse necessário comparar alguns números sobre a renovação dos quadros de diretoria, à luz de um dos critérios de "democracia", que envolve a possibilidade de emergência de oposições e de disputas eleitorais ${ }^{22}$. Os registros que encontramos são poucos, mas acreditamos que sejam suficientes para destacar alguns elementos. A tabela 1 especifica tais números.

\footnotetext{
${ }^{21}$ Correspondência recebida pela Intendência Municipal de Pelotas - Instituições civis - 8 maio 1908; 29 dez. 1909; [maio 1914?] (maço 57 - BPP). Para a Grã-Bretanha da passagem do século XVIII para o século XIX, consta que as "independent local societies were run by a self-perpetuating comitee", NEAVE, David. Friendly societies in Great Britain. In: LINDEN, Marcel Van Der (ed.). Social security... op. cit., p. 53. e MAC CORD, Marcelo. Andaimes, casacas, tijolos e livros: uma associação de artífices no Recife, 1836-1880. Campinas: UNICAMP, (Tese, doutorado em história), 2009, p. 300.

${ }^{22}$ MORAIS, Jorge Ventura de. "Novo" sindicalismo e democracia sindical: um teste e uma crítica ao modelo eleitoral. Dados-Revista de Ciências Sociais. Rio de Janeiro: [s.e.], Vol. 38, no. 3, pp. 545-579, [s.m.], 1995.
} 
Tabela 1

Dirigentes e cargos em mutuais selecionadas (RS, 1854-1939)

\begin{tabular}{|c|c|c|c|c|c|}
\hline Entidade & Período & Postos & Sócios & Índice & Observações \\
\hline Sociedade de Beneficência Porto-Alegrense & $1857-1872$ & 61 & 46 & 0,75 & (lacunar) \\
\hline Sociedade de Beneficência Porto-Alegrense & $1857-1859$ & 25 & 17 & 0,68 & \\
\hline Sociedade de Beneficência Porto-Alegrense & $1867-1872$ & 28 & 25 & 0,89 & \\
\hline $\begin{array}{l}\text { Sociedade Portuguesa de Beneficência (Rio } \\
\text { Grande) }\end{array}$ & 1889-1903 & 25 & 63 & 0,43 & \\
\hline $\begin{array}{l}\text { Sociedade Portuguesa de Beneficência (Rio } \\
\text { Grande) }\end{array}$ & $1889-1896$ & 30 & 69 & 0,40 & \\
\hline Deutscher Hilfsverein (Porto Alegre) & $1858-1884$ & 145 & 71 & 0,49 & (lacunar) \\
\hline $\begin{array}{l}\text { Societé Française de Bienfaisance (Porto } \\
\text { Alegre) }\end{array}$ & $1868-1894$ & 31 & 17 & 0,55 & (lacunar) \\
\hline Club Beneficente 24 de Maio & $1910-1914$ & 68 & 48 & 0,71 & $\begin{array}{l}\text { c/ diretores de } \\
\text { mês e } \\
\text { comissão de } \\
\text { contas }\end{array}$ \\
\hline Club Beneficente 24 de Maio & $1910-1914$ & 32 & 23 & 0,72 & \begin{tabular}{l}
\multicolumn{2}{l}{ s/ diretores de } \\
mês \\
comissão de \\
contas
\end{tabular} \\
\hline $\begin{array}{llll}\begin{array}{l}\text { Sociedade } \\
\text { (Pelotas) }\end{array} & & \\
\end{array}$ & $1857-1925$ & 69 & 21 & 0,30 & presidentes \\
\hline $\begin{array}{l}\text { Sociedade Portuguesa de } \\
\text { (Pelotas) }\end{array}$ & Séc. XIX & 44 & 14 & 0,32 & presidentes \\
\hline $\begin{array}{l}\text { Sociedade Portuguesa de } \\
\text { (Pelotas) }\end{array}$ & Séc. XX & 25 & 8 & 0,32 & presidentes \\
\hline $\begin{array}{l}\text { Sociedade Portuguesa de Beneficência (Porto } \\
\text { Alegre) }\end{array}$ & 1854-1939 & 93 & 37 & 0,40 & presidentes \\
\hline $\begin{array}{l}\text { Sociedade Portuguesa de Beneficência (Porto } \\
\text { Alegre) }\end{array}$ & Séc. XIX & 51 & 27 & 0,53 & presidentes \\
\hline $\begin{array}{l}\text { Sociedade Portuguesa de Beneficência (Porto } \\
\text { Alegre) }\end{array}$ & Séc. XX & 42 & 12 & 0,29 & presidentes \\
\hline Club Caixeiral (Pelotas) & $1880-1886$ & 55 & 31 & 0,56 & $\begin{array}{l}\text { s/ diretores de } \\
\text { mês (n. geral } \\
\text { de eleições) }\end{array}$ \\
\hline Club Caixeiral (Pelotas) & $1880-1886$ & 16 & 31 & 1,94 & $\begin{array}{l}\text { s/ diretores de } \\
\text { mês (cargos } \\
\text { disponíveis) }\end{array}$ \\
\hline Club Caixeiral (Pelotas) & $1880-1886$ & 167 & 91 & 0,54 & $\begin{array}{l}\text { c/ diretores } \\
\text { (n. geral de } \\
\text { eleições) }\end{array}$ \\
\hline Club Caixeiral (Pelotas) & $1880-1886$ & 128 & 91 & 0,71 & $\begin{array}{l}\text { c/ diretores } \\
\text { (cargos } \\
\text { disponíveis) }\end{array}$ \\
\hline
\end{tabular}

Fonte: elaboração do autor.

Notamos que, em alguns casos, encontramos apenas o nome dos presidentes e que, em outros, especificamos parcelas dos grupos dirigentes. $O$ índice, trazido na quinta coluna, resulta da divisão do número de sócios pelo número de cargos, o que poderia ser interpretado como um índice de renovação dos grupos dirigentes. Uma 
democracia perfeita, na qual os postos da diretoria seriam uma única vez ocupados por cada um dos membros geraria índices próximos de 1, quando, ao longo do tempo, uma pessoa nunca ocupa mais do que uma vez cargos em diretorias, de forma que, considerando a obrigatoriedade do exercício de cargos, todos aqueles com direitos políticos teriam a experiência de administração. Há poucas entidades com índices próximos de 1 e os modelos mais próximos seriam os da Sociedade de Beneficência Porto-Alegrense e do Club Beneficente 24 de Maio, também de Porto Alegre. Podemos observar que todas as Sociedades Portuguesas de Beneficência têm elevada tendência oligárquica, mas não tão elevada quanto aquela encontrada na Santa Casa de Misericórdia, de Pelotas, que era de $0,26^{23}$. Não obstante, seria previsível que uma maior tendência democrática nessas mutuais, revelar-se-ia quando o mesmo grupo sofre uma rotação de cargos na diretoria, o que geraria números mais próximos de uma democracia, quando os presidentes poderiam variar. A previsão de que os presidentes variam não se realiza, porque na mutual de Rio Grande, quando calculado o índice exclusivamente para presidentes entre 1889 e 1903, ele cai de 0,43 para 0,2. A tendência oligárquica das Sociedades Portuguesas de Beneficência também aparece no Hilfsverein, permitindo indagar o quanto a oligarquia é necessária para a constituição da "identidade" étnica, suposição que ganha mais consistência quando levada em conta a necessidade de consolidar uma retórica que una interesses materiais e espirituais, algo mais provável de ocorrer quanto menores são os retores autorizados pela posição de dirigente. Essa suposição não é enfraquecida pelo índice superior de "democracia" na mutual francesa de Porto Alegre, porque sua, por assim dizer, "invisibilidade" foi tamanha que um historiador tradicional só encontrou registros dela até 1868 , mesmo que outros registros confirmem sua existência por, pelo menos, mais trinta anos. A mutual é de tal forma ignota que jamais encontramos, na bibliografia, qualquer referência suspeitando de vínculos étnicos ou religiosos judaicos na entidade, a despeito de membros de seu grupo dirigente terem sobrenomes como Israël, Levy e Aaron. ${ }^{24}$

Ressalvada a carência de mais registros, a tabela revela ainda que as entidades são diferentes. A Sociedade Portuguesa de Beneficência, em Porto Alegre, foi mais oligárquica no século XX do que no século XIX. Contudo, não há essa variação na de

\footnotetext{
${ }^{23}$ TOMASCHEWSKI, C. Caridade e filantropia na distribuição da assistência: a Irmandade da Santa Casa de Misericórdia de Pelotas - RS (1847-1922). Porto Alegre: PUCRS (Dissertação, mestrado em história), 2007, p. 98 et seg.

${ }^{24}$ SPALDING, Walter. Os franceses no Rio Grande do Sul. In: BEUX, Armindo (org.). Franceses no Rio Grande do Sul. Porto Alegre: Metrópole, 1976, pp. 41-42. Para o funcionamento da Societé Française no escritório da agência consular, cf.: A Federação. Porto Alegre, 5 ago. 1892 e 31 jan. 1895 e Correspondência das Associações de Beneficentes [sic] em resposta a questionário enviado à Diretoria Geral de Estatística, 1897. Estatística. Maço 4. (AHRS).
} 
Pelotas. Por outro lado, índices mais elevados de "democracia" são, antes, resultado de caos administrativo, como ocorre no Clube Caixeiral, de Pelotas, que chegou a eleger duas diretorias no primeiro ano de sua existência e ainda teve que substituir membros desistentes ${ }^{25}$. Da mesma forma, a Sociedade de Beneficência PortoAlegrense possuiu um índice elevado de "democracia" entre 1867 e 1872, porque, amiúde, as diretorias renunciavam a seus postos. Devemos notar que os membros que são "diretores de mês" (fiscais de socorros, com mandatos breves) ou membros das comissões de contas (com mandato brevíssimo) fazem pouca diferença se incorporados ou não ao cálculo do índice, como observamos no Caixeiral e no 24 de Maio. Esses cargos são, no máximo, recursos para o recrutamento de novos membros do grupo dirigente, mas há casos em que o sócio é incorporado a novas diretorias sem a passagem preliminar por esses postos, como acontece com $\mathrm{H}$. C. Bojunga, adjunto de tesoureiro, na diretoria de 1886, mas que nunca havia ocupado cargo de diretor.

Obter o índice é uma operação aritmética posterior à busca de informações, mas ele, por si só, nada revela. Pode apresentar elementos na comparação com outras entidades e pode revelar situações nas quais é mister atentar para os processos de escolha de diretorias. Tomando, portanto, exemplos da mesma tabela, nunca encontramos, além de seus documentos, referências mais densas sobre o Club Beneficente 24 de Maio: é uma associação sobre a qual os pesquisadores não prestaram atenção, mas o índice de renovação de seus dirigentes nos leva a perguntar o que é essa entidade. O seu estatuto revela apenas que é uma mutual aberta. Já os relatórios realizados entre 1911 e 1914 mostram que contava, entre seus membros, com líderes operários, policiais de alta patente e pessoas com sobrenomes estrangeiros. Contudo, suas diretorias tendiam a concentrar oficiais militares. 0 presidente de 1910 era um tenente do $56^{\circ}$ Batalhão de Caçadores, transferido para o Rio de Janeiro durante o seu mandato. O tenente-coronel João Pedro do Rosário ocupou o cargo de tesoureiro por vários anos e o capitão que foi eleito para a presidência em 1911 trabalhava junto ao presidente do estado. Nem sempre as patentes apareciam junto às nominatas de diretoria, mas o relatório de 1914, louvando a volta de João Pedro do Rosário ao cargo de tesoureiro (agora, já com a patente de coronel), traz um parecer da comissão de contas que revela que, apesar de ser uma mutual aberta, ela se ocupa da moralidade de seus sócios, porque ele demonstrava "mais uma vez que a probidade e zelo de que sempre deu provas nas

\footnotetext{
25 Algo semelhante ao que ocorreria, na União Beneficente dos Chauffeurs de Santa Catarina, como narra LEUCHTENBERGER, Rafaela. "O Lábaro protetor da classe operária". As Associações voluntárias de socorros-mútuos dos trabalhadores em Florianópolis - Santa Catarina (1886-1932). Campinas: UNICAMP, (Dissertação, mestrado em história), 2009, pp. 109-110.
} 
árduas funções de militar, que exerceu por longo período de tempo, são predicados que o acompanham sempre em todos os atos de sua vida". Essa comissão de contas, como previsível, também se compunha de um major, de um capitão e de um $1^{\circ}$ tenente $^{26}$. Esses elementos, invisíveis ainda na mera obtenção de índices de ocupação de cargos, são suficientes para configurar a mutual como fechada? E quanto à sociabilidade interna, pautava-se por códigos estamentais militares? O exemplo oposto ao da "democracia" do 24 de Maio pode ser encontrado na Sociedade Portuguesa de Beneficência, de Rio Grande, que manteve os mesmos presidente e vice-presidente entre 1889 e 1895. Antônio Joaquim Pinto da Rocha e Manoel Carlos de Lima Torres teriam assumido os cargos depois de um período em que "quase sempre apareciam chapas de oposição à oficial, ocasionando a convocação de várias assembléias para a eleição de novas chapas, ou de cargos vagos por renúncia". Em 1892, a reeleição ocorreu em meio a uma disputa entre duas chapas, cujo resultado foi a vitória de Rocha por setenta e cinco votos contra cinquenta e um. Em 1895, foram necessárias três assembleias para compor a diretoria, devido a renúncias e disputas. ${ }^{27}$ O baixo índice suporia um baixo grau de "democracia" na entidade, mas a existência de disputas indica a existência de uma oposição constante e a compreensão de que o momento eleitoral é legítimo, ou seja, de que as assembleias gerais são os lugares privilegiados dessas disputas.

Se as assembleias gerais são os lugares privilegiados das disputas eleitorais, supõe-se que sua existência e sua legitimidade, ao estimularem a sociabilidade interna, levariam as escalas de valores a unirem interesses materiais e espirituais, sobretudo porque, nelas, far-se-ia o uso da palavra em atos retóricos já mencionados. Para o prazer dos historiadores, as assembleias onde existem disputas - e mesmo as entidades onde tais disputas existem - são as mais informativas sobre os valores em

\footnotetext{
${ }^{26}$ RELATÓRIO do Club Beneficente 24 de Maio apresentado pelo $1^{\circ}$ Secretário no exercício do cargo de Presidente $2^{\circ}$ Tenente Oscar Coelho de Castro em sessão de Assembléia Geral, em 16 de Julho de 1911, ao empossar seu sucessor no exercício do cargo. Julho de 1910 a Junho de 1911. Porto Alegre: Officinas Graphicas da Livraria do Globo, 1911; RELATÓRIO do Club Beneficente 24 de Maio apresentado por João de Oliveira Bandeira, Vice-presidente no cargo de Presidente em sessão de Assembléia Geral, em 18 de Julho de 1912, ao empossar seu sucessor no exercício do cargo. Julho de 1911 a Junho de 1912. Porto Alegre: Officinas Graphicas da Livraria Americana, 1912; RELATÓRIO do Club Beneficente 24 de Maio apresentado por João de Oliveira Bandeira, Presidente. Em sessão de Assembléia Geral em [?] de Julho de 1913, ao empossar seu sucessor no exercício de seu cargo. Julho de 1912 a Junho de 1913. Porto Alegre: Officinas Graphicas da Livraria do Globo, 1913; RELATÓRIO do Club Beneficente 24 de Maio apresentado pelo Presidente José de Carvalho em sessão de Assembléia Geral em 5 de Agosto de 1914, ao empossar a nova Diretoria. Julho de 1913 a Junho de 1914. Porto Alegre: Livraria Americana-Cunha, Tenzsch \& C., 1914 (IHGRGS).

${ }^{27}$ SINTRA, Elmano de. Sociedade Portuguesa de Beneficência: História da Sociedade Portuguesa de Beneficência do Rio Grande, através de um século: 1859-1959. Porto Alegre: Of. Gráf. da Livraria do Globo, 1959, pp. 49-52.
} 
jogo. Embora nem todos os sócios possam participar de diretorias - e existem prescrições como a de exclusão dos analfabetos ou a necessidade de que os tesoureiros tenham dinheiro próprio - participar dela só é um recurso ou um benefício quando acarreta prestígio. Aparentemente, a Sociedade Portuguesa de Beneficência, de Rio Grande, prestigiava seus diretores no começo do século $X X$, quando se verifica que o comendador Pinto da Rocha, que por anos ocupara a presidência, a exerce, pela última vez, em 1903. Em 1904 e 1905, o comendador preside a Associação dos Empregados no Comércio do Rio Grande, com uma diretoria que também contava com José Antônio Mendizabal, membro da "galeria ilustre" do Clube Caixeiral de Pelotas, por ter sido fundador e, várias vezes, eleito para diferentes cargos.

As diretorias, porém, não eram poderes autocráticos, porque três entidades de Rio Grande prescreveram medidas de separação entre o exercício de cargos e a vida privada. Na Beneficência dos Artistas e na Protetora das Famílias, era proibido que parentes ocupassem cargos na mesma diretoria e, na Sociedade Portuguesa de Beneficência, a diretoria poderia fornecer "atestado de serviços" (?) mas nunca a membros da própria diretoria. Além disso, as diretorias não eram autocráticas apenas devido ao processo de eleição, mas também pela possibilidade de que seus membros fossem depostos por outros órgãos de decisão, sobretudo a assembleia geral, tal como ocorreu, por exemplo, na 24 de Maio, na Pradense de Mútuo Socorro, na União Caixeiral Jaguarense e no Grêmio Tipográfico, em Pelotas. A geração de prestígio não ocorreu, necessariamente, por efeito da ocupação de cargos na diretoria, mas, como antes argumentamos, por efeitos retóricos. A "galeria ilustre" do Clube Caixeiral, em Pelotas, tal como reportada em 1904, era integrada, por exemplo, por Arthur Nova Monteiro, qualificado como "membro influente", morto em 1884, mas que só ocupou o cargo de diretor de mês em 1882 e 1884; Sizínio R. de Carvalho, que aparece como "iniciador" do movimento pelo fechamento de portas, ocupante de diversos cargos, etc., mas que, realmente, só ocupou o cargo de diretor de mês entre 1880 e 1886; e Manoel Morales, o primeiro presidente, que não ocupou mais cargo algum e que sequer aparece na lista de fundadores do Club, em 1904, apesar de suas memórias terem sido resgatadas na década de $1920^{28}$. Um outro elemento que contribuiu para

\footnotetext{
${ }^{28}$ ESTATUTOS do Club Beneficente 24 de Maio. Aprovados em sessão de Assembléia Geral realizada em 8 de abril de 1908. Porto Alegre: Officinas a Vapor da Livraria do Comércio, s/d; ESTATUTO da Sociedade Pradense de Mútuo Socorro. Fundada em 22 de Novembro de 1911. Antônio Prado: Typ. Cesa, 1942 (CD AIB-PRP); ESTATUTOS do Gremio Typographico. Aprovados em assembléia geral no dia 2 de fevereiro de 1881. Pelotas: Typ. da Livraria Americana, 1881 (NPH); ESTATUTOS da União Caixeiral Jaguarense, op. cit. RELATÓRIO da Associação dos Empregados no Comércio do Rio Grande no ano de 1904. Rio Grande do Sul: Typographia da Livraria Rio-Grandense, 1905; RELATÓRIO da Associação dos Empregados no Comércio do Rio Grande relativo ao ano de 1905. Rio Grande: Officinas a vapor d'O Intransigente, 1906 (BRG); NOTÍCIA Histórica. In: CLUB CAIXEIRAL. Relatório apresentado à Assembléia Geral de 25 de
} 
que as diretorias não fossem qualificadas como autocráticas foi o "espírito público" que deveria orientá-las quando do exercício de cargos. A diretoria da Liga Operária de São Borja deveria tomar decisões sobre diversos eventos, levando em conta "os interesses gerais, sem descurar o interesse de cada um". A fórmula prescrita, nesses estatutos, não tem outro conteúdo efetivo do que a definição de um valor de conduta que se realiza, por exemplo, quando as mutuais estabelecem concorrências para aquisição de bens e de serviços ou concursos para a contratação de empregados ${ }^{29}$.

Se o exercício de cargos, na entidade, nem sempre trazia prestígio ou benefícios (a ponto de ser, amiúde, obrigatório) e, mesmo quando trazia, impunha ao eleito tarefas (executadas também conforme regras) e responsabilidades (pelas quais poderia ser cobrado e, mesmo, deposto), é previsível que haja uma baixa renovação nos quadros de dirigentes, como evidencia a tabela 1. Não obstante, existem eleições e disputas eleitorais. As disputas eleitorais aconteciam em um procedimento bem descrito, no estatuto da Associação dos Maquinistas da Marinha Mercante, "Cada associado votará em uma só cédula na qual escreverá: Diretoria - e em seguida os nomes dos seus candidatos pela ordem administrativa, depois a palavra Conselho - e os nomes de seus candidatos a esses cargos $^{\prime \prime 30}$. Com o resultado desse procedimento, é composto o grupo dirigente. Por meio desse processo, era possível saber os votos que cada um dos membros desse grupo dirigente obtinha. Na Sociedade de Beneficência Porto-Alegrense, utilizava-se uma "chapa" (cédula) por cargo, de modo que um mesmo sócio podia, na mesma eleição, obter votos para diferentes cargos. Apenas como exemplo, apresentamos, no quadro 2, os resultados parciais das eleições de 1857 e de 1858 da Sociedade de Beneficência Porto-Alegrense.

dezembro de 1904 pelo presidente Antonio Tronca Duarte. Pelotas/Rio Grande: Officinas da Livraria Comercial, [s.d.], p. 96 (BPP).

${ }^{29}$ ESTATUTOS da Liga Operária em São Borja. Monte Caseros: Establecimiento Tipografico Porvenir, 1904 (NPH, IHGRGS). e LORENZONI, Júlio. Memórias de um imigrante italiano. Porto Alegre: Sulina, 1975, pp. 123-126.

${ }^{30}$ ESTATUTOS da Associação dos Machinistas da Marinha Mercante. Rio Grande: Typ. do Diário do Rio Grande, 1907 (BRG) 
Quadro 2: Resultados parciais de eleições na

Sociedade de Beneficência Porto-Alegrense (1857 e 1858)

\begin{tabular}{|c|c|c|c|c|c|c|c|c|c|c|c|c|}
\hline \multirow{2}{*}{$\begin{array}{c}\text { Nome } \\
\text { Ano } \\
\end{array}$} & \multicolumn{2}{|c|}{ Presidente } & \multicolumn{2}{|c|}{$\begin{array}{l}\text { Vice- } \\
\text { presidente }\end{array}$} & \multicolumn{2}{|c|}{ Secretário } & \multicolumn{2}{|c|}{ Tesoureiro } & \multicolumn{2}{|c|}{ Adjunto } & \multicolumn{2}{|c|}{ Procurador } \\
\hline & 1857 & 1858 & 1857 & 1858 & 1857 & 1858 & 1857 & 1858 & 1857 & 1858 & 1857 & 1858 \\
\hline $\begin{array}{ll}\text { Antonio } & \text { José } \\
\text { Lourenço } & \end{array}$ & 30 & 2 & & & & & & 25 & & & & \\
\hline $\begin{array}{lll}\text { [Félix] Xavier da } \\
\text { Cunha }\end{array}$ & 3 & 42 & 11 & & & & 22 & & & & & \\
\hline Leonel & & & & & 28 & 30 & & & & 34 & & \\
\hline $\begin{array}{l}\text { Espiridião [José } \\
\text { Muniz] }\end{array}$ & & & & & 23 & & & & & & & \\
\hline Augusto & & & 17 & 18 & & & & 18 & & & & \\
\hline Tobino & & & 4 & & & & & & & & & \\
\hline Borges & & & 1 & & & & & & & & & \\
\hline Firmino & & & & & & & & & 30 & & & 18 \\
\hline Firmo & & & & & & & & & 26 & & & 26 \\
\hline Vieira & & & & & & & & & 25 & & & \\
\hline Formel & & & & & & 28 & & & 19 & & & \\
\hline Ferrugento & & & & & & & & & 12 & & & \\
\hline Pereira Jr. & & & & 26 & & & & & & & & \\
\hline Oliveira Ramos & & & & & & & & & & 28 & & \\
\hline Manuel Assumpção & & & & & & & & & & 27 & & \\
\hline Juvencio & & & & & & & & & & 26 & 21 & \\
\hline Valle & & & & & & & & & & 25 & & \\
\hline
\end{tabular}

Fonte: LIVRO de atas das sessões da Sociedade de Beneficência Porto-Alegrense, 1856-1860, op. cit., fls. 18-19 e 37.

A despeito do pequeno número de votos, são visíveis alguns fenômenos, como a presença de trinta e seis votos, em Félix Xavier da Cunha, para diferentes cargos, em março de 1857, e sua eleição para presidente, com quarenta e dois votos, no ano seguinte, invertendo as posições com o primeiro presidente, Antônio José Lourenço. Já o sócio Augusto, por exemplo, teve cerca de dezessete votantes constantes para diversos cargos e o sócio Firmo teve vinte e seis preferências. Elencar todas as preferências eleitorais de cada entidade, ao longo de vários anos, configuraria, com mais precisão, a composição do grupo dirigente. Quando antes mencionamos que Pereira Jr. protestou contra a "cabala" para o eleger vice-presidente, podemos ver, no quadro 2, que ele não havia exercido cargo algum na gestão anterior. O livro de atas não é claro sobre o porquê da combinação entre os sócios e qual o significado da votação divergente para o mesmo cargo, em 1858, em Augusto. Por outro lado, após essa eleição, Augusto acabou exercendo o cargo de tesoureiro, devido ao pedido de dispensa (por doença) de Antônio José Lourenço. Terá sido um pedido sincero? Uma fuga do desconforto, na gestão, com certas pessoas? Uma gentileza com Augusto? Infelizmente, nem o livro de atas o revela de modo explícito, mas apenas queremos 
chamar a atenção para o conjunto de variáveis que podem ser reveladas, no momento de eleições, em sociedades de socorros mútuos.

Seriam esses momentos exatamente "políticos"? Podem ser, em alguns casos, mas uma caracterização mais genérica envolveria os elementos concernentes a uma mais intensa sociabilidade em reuniões de diretoria. O próprio sistema eleitoral, normalmente, adotado torna difícil uma interpretação política das disputas. Nas eleições do Clube Caixeiral, em Pelotas, foram apresentadas pela imprensa duas chapas, a Reformista e a Ypiranga, em um total de dezessete a dezoito cargos disputados. Ao contrário da previsão de que haveria trinta e nove candidatos, havia apenas vinte e nove, porque mais da metade dos concorrentes, em cada chapa, constam também nos mesmos ou em outros cargos na outra. Talvez, o Clube Caixeiral tivesse alto índice de "democracia", conforme a tabela 1, porque era comum a existência de mais de uma chapa, nessas mesmas condições de repetição, tal como também aconteceu em 1885 (três chapas) e em 1887 (duas chapas). Embora não tenhamos trabalhado com a eleição de 1882, um artigo de jornal menciona que, passado o pleito vencido pelos Jequitibás, estes "aprisionaram os vencidos [Tamanduás] [...] na fortaleza Restaurante Silva [...]", deixando claro o peso da sociabilidade na disputa ${ }^{31}$.

Nem sempre as eleições eram tranquilas. Na Sociedade de Beneficência PortoAlegrense, houve dois momentos de crise relacionados ao processo eleitoral. No primeiro deles, em 18 de março de 1860, Luiz Francisco Cavalcanti de Albuquerque requereu a "chapa lista" para eleição da diretoria, isto é, que a nominata fosse fechada e não aberta, como ocorria. Derrotada a proposta, requereu "que a Assembléia pudesse suspender do exercício de seu cargo os membros da diretoria", no que foi também derrotado. Algumas semanas depois, ocorreu um novo debate sobre o papel da diretoria, às vésperas de uma nova eleição. Infelizmente, o livro de atas se interrompe antes da eleição de 1860 , mas sabemos que, nessa data, foi fundada a Beneficência Brasileira União, cujos sócios e primeiros diretores foram, exatamente, os que vinham debatendo as funções da diretoria. Como não são claros os termos exatos da disputa, limitamo-nos a imaginar se a proposta de "chapa lista", se vitoriosa, evitaria a divisão, ainda que os grupos já estivessem se definindo, em 20 de novembro de 1859, quando Cavalcanti de Albuquerque teria afirmado que "havia partidos na sociedade". O segundo momento foi, em 15 de março de 1872, quando a mutual

\footnotetext{
${ }^{31}$ Agradecemos a Beatriz Ana Loner por nos ter cedido seus fichamentos de jornal, que incluem: Correio Mercantil. Pelotas, 9, 20 e 26 nov. 1880; 27 e 28 nov. 1885; 24 e 25 nov. 1887. Sobre a eleição de 1882, o trecho citado consta em: O Pervigil. Pelotas, 3 dez. 1882, p. 3 (BPP). De resto, o mesmo procedimento de composição de chapas havia na Classes Laboriosas da mesma cidade: A Discussão. Pelotas, 13 e 15 dez. 1887.
} 
estava sob intervenção do presidente da província, que nomeava seu presidente. Uma reunião não oficial, em 10 de março desse ano, deliberou pedir ao presidente da província que nomeasse, para a presidência da Porto-Alegrense, Aurélio Bittencourt, que, então, ocupava a vice-presidência. Contudo, o executivo provincial reconduziu o presidente Antônio José Lourenço, que se viu em maus lençóis: Aurélio Bittencourt cobrou, em assembleia geral, a conduta de Lourenço e esta foi condenada. O caso pode mesmo ter um fundo político, mas os termos utilizados exprimem, antes, o caráter emotivo do compartilhamento de responsabilidades na diretoria. $02^{\circ}$ secretário interino

\begin{abstract}
declarou retirar toda a sua confiança e amizade ao atual Presidente, visto haver-Ihe afiançado sob sua palavra de honra que não só no ofício de remessa ao Presidente da Província faria ciente da resolução tomada pela reunião do dia 10, como iria pessoalmente pedir a S. Ex.a a nomeação de Presidente da Sociedade para o atual Vice-presidente, e no entanto zombou de uma corporação de homens que o acreditavam decidido pugnador dos interesses da casa. ${ }^{32}$
\end{abstract}

Seria realmente possível definir este último caso como disputa política? Ou seria melhor pensar que vários dos eventos que ocorreram, nas mutuais - o que inclui as disputas eleitorais -, se revestiram do mesmo tipo de combinação de seguro e de sociabilidade, de direito e de convenção, de razão e de afeto que orienta as deliberações sobre estatutos e outros debates?

Ora, o local privilegiado desses debates só pode ter sido a assembleia geral, onde se reuniam os que possuíam todos os direitos. É verdade que nem todas as entidades valorizavam as assembleias gerais, e que, inclusive, existiram mutuais que dificilmente poderiam ser qualificadas de "democráticas". Não obstante, é comum a declaração que atribui ao órgão o "supremo poder" ou o "poder supremo", a "autoridade superior", ou até que as deliberações desse órgão "são definitivas". A Caixa de Socorros Marquês de Pombal, em Pelotas, carregava, no estilo (e, portanto, na retórica), ao definir assembleias como "poder soberano e legislador da sociedade e, como tal, um tribunal augusto". Essa valorização das assembleias gerais não se compunha, aparentemente, de palavras vazias, porque outros procedimentos prescritos, em estatutos, eram coerentes com a avaliação. A Union Française, em Pelotas, e a Giuseppe Mazzini, em Quaraí, previam assembleias mensais. A Unione e

\footnotetext{
${ }^{32}$ Sessões de assembleia geral de 5 fev., 18 mar. 1860 e 20 nov. 1859. LIVRO de atas das sessões da Sociedade de Beneficência Porto-Alegrense, 1856-1860, op. cit., fls 89, 98, 82-83; Sessão de assembleia geral de 15 mar. 1872. LIVRO de atas das sessões da Sociedade de Beneficência Porto-Alegrense, 18671873, op. cit., fl. 106.
} 
Filantropia, em Pelotas, previa seis assembleias anuais e a Classes Laboriosas, na mesma cidade, previa cinco. A Sociedade União Operária, em Rio Grande, estabelecia quatro assembleias anuais, número semelhante ao das entidades que previam a periodicidade trimestral, como a Marquês do Pombal, a Brasileira União, em Porto Alegre, e a Umanitária [sic], em Camaquã. Contudo, a maior parte das mutuais estabelecia uma assembleia anual para a prestação de contas, a eleição e a posse da nova diretoria ${ }^{33}$.

Independente do número de assembleias previstas, o comparecimento às assembleias gerais não era definido como um direito do associado, mas como um dever, tal como acontecia, no Club Caixeiral e na Unione e Filantropia, ambos de Pelotas, ou, ainda, na União Filhos do Trabalho, de Uruguaiana. A Auxiliadora da Picada Dois Irmãos, de São Leopoldo, e a Union Française, de Pelotas, são apenas exemplos de entidades que chegaram a estabelecer multas aos sócios que faltassem a assembleias, vinculando, de modo estreito, a participação política e o interesse material ${ }^{34}$. Mas era mesmo uma participação política? Há diversos elementos que nos permitem matizar a participação, na assembleia geral, como um direito político, e não nos referimos apenas à prescrição existente, em alguns estatutos, de que ela é um dever. De certo modo, estão todos incorporados à formalização que amiúde é prevista quando da reunião da instância. O estatuto de 1902 da Unione e Filantropia, em Pelotas, detalha o processo de debate, que citamos abaixo:

Art. $25^{\circ}$ - Nenhum sócio poderá falar mais de duas vezes sobre cada matéria
em discussão, exceto os relatores, ou presidentes de comissão e os autores
de requerimentos, indicações, propostas ou moções que poderão falar mais
uma vez, e o orador que falará sempre que pedir a palavra.
$\S 1^{\circ}$ - Se depois de qualquer sócio ter esgotado o número de vezes em que
pode falar, forem apresentadas novas emendas, ser-lhe-á concedida a
palavra uma vez mais, mas somente sobre as emendas, não lhe sendo mais
permitido entrar na discussão da matéria principal.
$\S 2^{\circ}$ - Quando dois ou mais sócios pedirem simultaneamente a palavra, o

${ }^{33}$ [ESTATUTOS da Caixa de Socorros Marquez de Pombal]. Ato n. 145 de 10 de outubro de 1882. [RIO GRANDE DO SUL]. Actos do Governo da Província do Rio Grande do Sul de 1882. Porto Alegre: Off. Typ. de Carlos Echenique, 1908; [ESTATUTOS da Union Française], op. cit., [ESTATUTOS da Sociedade Comemorativa e Beneficente Giuseppe Mazzini-Quaraí], 1888. (AHRS-Requerimentos, Diversos, Maço 258); ESTATUTO da Sociedades [sic!] Italiana Reunidas União Filantropia e Circolo Garibaldi. [Livro A-1, FIs 1, n. 1, em 11 out. 1902. FBL]; ESTATUTOS da Sociedade União Operária. Rio Grande: Typ. Do Diário do Rio Grande, 1903 (NPH); [ESTATUTOS da Sociedade de Beneficência Brasileira União], 1861. (AHRSRequerimentos, Diversos, Maço 98); [ESTATUTOS da Sociedade Umanitária], 1873. (AHRSRequerimentos, Diversos, Maço 163).

${ }^{34}$ ESTATUTOS do Clube Caixeiral da Cidade de Pelotas. Pelotas: Typ. da Livraria Americana, [1880?]. (BRG); ESTATUTOS da Sociedade Beneficente União Filhos do Trabalho. Uruguaiana: Tip. A Nação, 1927 (BRG); [ESTATUTOS da Sociedade Auxiliadora da Picada Dois Irmãos], 1862. (AHRS- Requerimentos, Diversos, Maço 99; [ESTATUTOS da Union Française], op. cit. 
presidente os fará inscrever por ordem, pelo secretário.

$\S 3^{\circ}$ - Depois de encerrada qualquer discussão, a ninguém mais é permitido usar da palavra, salvo pela ordem para propor o melhor modo de votação. A palavra pela ordem somente será concedida para encaminhar a discussão em votação.

Art. $26^{\circ}$ - Ninguém poderá falar sem primeiro obter permissão devendo ser sempre o discurso dirigido ao presidente ou à assembléia.

Art. $27^{\circ}$ - Toda discussão será encerrada pelo sócio que tiver opinião contrária à matéria do projeto, ou proposta que se discutir, e em seguida falarão os sócios alternadamente, um pró e outro contra.

$\S 1^{\circ}$ - O pedido de encerramento ou adiamento é votado sem discussão.

$\S 2^{\circ}$ - O orador da sociedade provando que a matéria não está suficientemente discutida poderá propor o adiamento, o que será aceito pelo presidente.

Art. $28^{\circ}$ - A nenhum sócio é permitido interromper quem estiver com a palavra, com apartes longos e repetidos que the façam perder o fio da discussão.

$\S$ único - O orador que se afastar da matéria que se discutir, ou divagar, ou se tornar inconveniente e pouco atencioso, será chamado à ordem pelo presidente, a primeira e segunda vez, e quando não atender às admoestações, Ihe será retirada a palavra, podendo o presidente, no caso de relutância, obrigá-lo a sair da sala da sessão.

Art. $29^{\circ}$ - Sempre que se trate de galardoar serviços ou de socorrer um sócio que se achar presente, deverá o sócio de que se tratar sair da sala de sessão, a convite do presidente, até que se encerre a discussão e se dê direção ou resolução ao assunto. ${ }^{35}$

Há três elementos importantes presentes nesse trecho. O primeiro que podemos julgar improvável, trata-se do detalhamento formulado sem levar em conta a experiência efetiva dos associados, na situação de assembleia geral, porque a referência a situações conhecidas por qualquer pessoa que ainda hoje compareça a esse tipo de instância evidencia o esforço em fazer da reunião não apenas um momento de convivência dos associados, mas uma sessão capaz de tomar decisões segundo procedimentos aceitos como legítimos por todos. Detalhar a legitimidade, portanto, é um meio de evitar questões de ordem ou de encaminhamento, sem, contudo, proibi-las. O segundo elemento é que, independente do detalhamento resultar ou não da experiência de assembleia, vários dos procedimentos são prescritos em outras mutuais, como, por exemplo, o do limite para tomar duas vezes a palavra, que também aparece no estatuto da União dos Professores do Rio Grande do Sul, ou a proibição de falar ao mesmo tempo, que também aparece na Protetora dos Artistas, de Bagé. Há estatutos que dispõem outros elementos, como o da Feliz Esperança, em Pelotas, que prescreve que o orador "usará de linguagem ao alcance de todos, para maior clareza". A formalização parece atingir o nível máximo, quando a Umanitária, de

\footnotetext{
${ }^{35}$ ESTATUTO da Sociedades [sic] Italiana Reunidas União Filantropia e Circolo Garibaldi. [Livro A-1, Fls 1,
} n. 1, em 11 out. 1902. [FBL] 
Camaquã, prescreve que todos deveriam falar de pé, na assembleia geral, com exceção do presidente e dos doentes. É também, nas assembleias gerais, que são empossados os novos eleitos para a diretoria, com direito a "juramento de estilo", como, por exemplo, o da Sociedade de Beneficência Porto-Alegrense, cuja invocação sagrada não deve obscurecer o compromisso do grupo dirigente que, por não pedir auxílio sobrenatural, assume a plena responsabilidade pelo exercício das funções: "Juro aos Santos Evangelhos desempenhar as obrigações inerentes a meu cargo e observar os estatutos" $^{\prime \prime 6}$. O terceiro elemento é que, mesmo que a palavra seja garantida em condições de igualdade para aqueles que possuem as virtudes capazes de exercê-la, como são definidos os que têm direitos políticos, as assembleias, nem sempre, são eficientes para passar do "interesse próprio" ao "interesse bem compreendido". Se o "interesse bem compreendido" supõe a existência de algum "espírito público", o público é, exatamente, o que faltava nas assembleias pouco frequentadas. Por isso, a identificação dos discursos e de seus eventuais sentidos, relacionados à satisfação de interesses espirituais não é suficiente sequer para caracterizar a conduta dos associados à mutual, quando muito de seus grupos dirigentes e dos frequentadores de assembleias gerais. 0 gráfico 1 revela alguns desses números.

\footnotetext{
${ }^{36}$ Respectivamente: ESTATUTOS da União dos Professores do Rio Grande do Sul. Porto Alegre: Gundlach, 1936 (IHGRGS); ESTATUTOS da Sociedade Protectora dos Artistas. Porto Alegre: Estabelecimento Typográphico de Gundlach \& Becker, 1899 (IHGRGS); ESTATUTO da Sociedade Beneficente Feliz Esperança. Pelotas: Typographia da Livraria Americana, 1897 (BPP); [ESTATUTOS da Sociedade Umanitária], op cit. Os trechos citados da Beneficência Porto-Alegrense encontram-se em: assembleias gerais de 14 abr. 1867 e 14 maio 1869. LIVRO de atas das sessões da Sociedade de Beneficência Porto-Alegrense, 1867-1873, op. cit., fls. 2 e 47.
} 
Gráfico 1 - Presença em sessões de mutuais escolhidas (RS, 1857-1940)

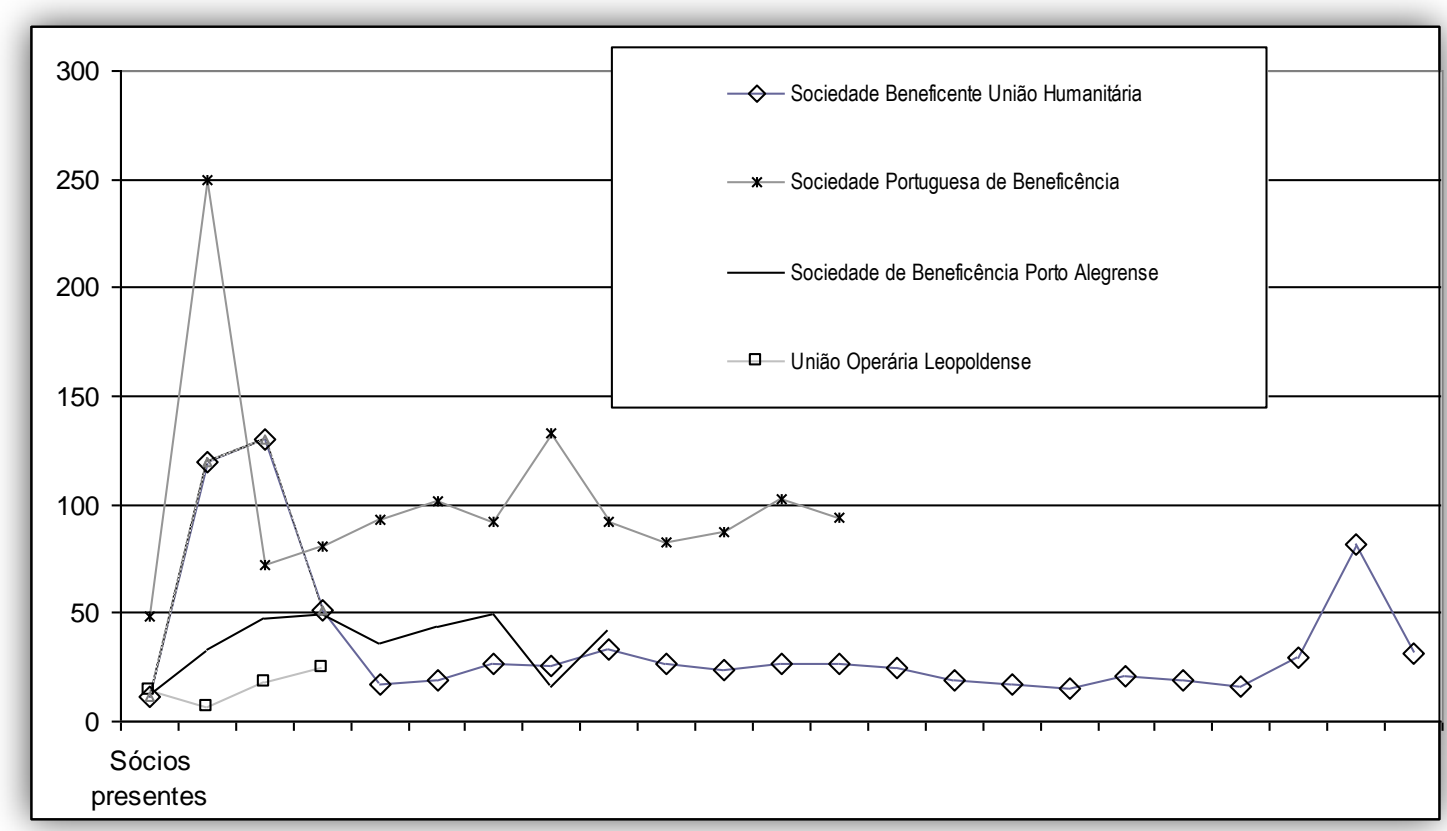

Fontes: LIVROS de atas das sessões da Sociedade de Beneficência Porto-Alegrense, 1856-1860 e 18671873; LIVROS de Presenças às sessões da Sociedade de Beneficência Porto-Alegrense, 1886-1890 e 1890-1903; RELATÓRIO da Sociedade Portuguesa de Beneficência relativo à gestão de $1^{\circ}$ de julho de 1925 a 30 de junho de 1926, apresentado e aprovado em Sessão de Assembléia Geral de $1^{\circ}$ de agosto de 1926 pelo presidente J. B. Eça de Queiroz. Pelotas: Off. Graphicas da A Guarany, 1926]; LIVRO de presenças em sessões de diretoria e Assembléia Geral da Associação Beneficente União Humanitária, 23 jan. 1922 - 1 dez. 1952 (BPP); MARIANO, Ibanes Oliveira. A União Operária Leopoldense. Monografia de conclusão do Curso de Licenciatura Plena em História - Universidade do Vale do Rio dos Sinos, 2001.

A tão citada Sociedade de Beneficência Porto-Alegrense não consegue reunir, em média, mais do que oitenta pessoas, nas suas assembleias gerais, a União Humanitária de Pelotas, mal reúne a metade desse número, na maior parte do seu período de existência, e a União Operária Leopoldense não excede os vinte e cinco membros em suas assembleias gerais. Uma das mutuais menos "democráticas" da tabela 1, a Sociedade Portuguesa de Beneficência, em Pelotas, reunia facilmente cem associados, nas suas primeiras assembleias gerais. Talvez, tal situação não seja específica da mutual portuguesa, porque a Sociedade de Beneficência PortoAlegrense, apesar de menor, também tendeu a aumentar o número de seus participantes nos primeiros anos das assembleias gerais de eleição de diretoria. Mas, é como se, passado algum tempo, consolidasse-se o grupo, cujo interesse fosse realmente "bem compreendido", porque os números da União Humanitária (fundada em 1898) e da União Operária (fundada em 1897) mantêm-se estáveis, com exceção dessa última entidade que tomou ânimo, no final do período coberto pelos dados, talvez em função da eleição presidencial no Brasil, como argumenta o autor do 
trabalho de onde provieram esses dados. O gráfico não deixa claro, mas sequer a ditadura do Estado Novo parece ter afetado (para menos?) a frequência nas assembleias da União Humanitária.

A assembleias pouco frequentadas são, amiúde, mencionadas. Os presidentes do Club Beneficente 24 de Maio, em Porto Alegre, lamentam a baixa participação dos sócios nas assembleias gerais, nos relatórios dos anos de 1911, 1912, 1913 e 1914. O primeiro desses relatórios ainda se reporta ao mesmo lamento por parte de "três ou quatro" antecessores. A Principe di Napoli, em Caxias, contaria com cento e vinte sócios, em 1895, e com cento e trinta sócios, em 1897, mas, as assembleias gerais que elegerem as diretorias, nesses anos, totalizaram, respectivamente, dezesseis e trinta e seis votos. Comparando os números totais de associação com duas das entidades exibidas no gráfico 1, verificamos que o grau de participação na União Humanitária parece ter sido superior, porque, dos oitenta e dois sócios existentes, em 1939, trinta e três participavam das assembleia gerais. Já na Sociedade de Beneficência PortoAlegrense, praticamente, nunca encontramos números confiáveis sobre o total de associados. Através de outras fontes, podemos estimar que quase $80 \%$ dos sócios não tinha interesse em participar da gestão da Sociedade de Beneficência Porto-Alegrense, seja por não comparecerem às assembleias gerais, seja por saberem que não teriam direitos políticos. O contato desses quase $80 \%$ de sócios com a entidade era feito, de um lado, pelo cobrador - não necessariamente um sócio - e, por outro, através do fiscal de mês, quando precisavam de socorros. É possível generalizar a afirmação sobre assembleias pouco frequentadas, porque o fenômeno não se restringiu ao Rio Grande do Sul ou às sociedades de socorros mútuos. Não é específico do Rio Grande do Sul porque o mesmo ocorria em quatro mutuais italianas, uma espanhola e uma francesa da cidade e da província de Buenos Aires e da província de Santa Fé e o número calculado de participantes não excedeu em 12,5\% dos membros. E não é específico de mutuais, porque o mesmo foi verificado em outros tipos de associação de teutos, no Rio Grande do Sul ${ }^{37}$.

Mencionamos, há pouco, o contato dos mutualizados com cobradores, sem assinalar que existia o risco desse personagem assumir poderes políticos imprevistos em estatutos, uma vez que, quando não existiam diretores de mês com funções de visita e de controle dos associados socorridos, como havia em várias mutuais, esses cobradores poderiam transformar-se, não apenas, nos responsáveis pela arrecadação

\footnotetext{
${ }^{37}$ Respectivamente: MARQUIEGUI, Dedier Norberto. Asociacionismo, liderazgo étnico e identidad: un enfoque comparado (Luján, 1876-1920). Studi Emigrazione. Roma: [s.e.], Vol. XXXI, no. 115, [s.m.], 1994, p. 436 e p. 452.; DEVOTO, Fernando J. Las sociedades... op. cit., p. 336; GERTZ, René. O perigo alemão. Porto Alegre: Ed. da Universidade-UFRGS, 1991, p. 51.
} 
das contribuições, mas naqueles cuja ação poderia levar a participação em assembleias e a deliberação de propostas ao êxito ou ao fracasso, tal como foi reportado para a cidade de Recife, na década de $1970^{38}$. Certamente, a derrota do interesse espiritual pelo interesse que, talvez, não fosse "bem compreendido" resultava da burocratização da mutual, ao substituir o contato interpessoal do sócio com seus iguais em proveito de maior eficiência na arrecadação. A Sociedade de Beneficência Porto-Alegrense também parece ter sofrido dessa burocratização, não só pela existência de cobradores, mas pela visível diferença entre a verborragia dos dois primeiros livros de atas em relação aos demais.

Essa é outra das tensões das mutuais, porque, como já argumentamos, sua eficiência na securitização dependeria da incorporação de novos associados e o fenômeno de crescimento pode tanto ampliar os indivíduos incorporados aos critérios de virtude decorrentes da formalização da sociabilidade, quanto despir a associação de quaisquer interesses espirituais. Isso significa avaliar os limites que a dimensão econômica do estudo das sociedades de socorros mútuos impõe à consecução dos objetivos concernentes à dimensão social. Existem, com efeito, alguns esforços para sanar esses problemas. O primeiro deles é, sem sombra de dúvida, o das assembleias gerais, que, mesmo quando vinculadas, em estatutos, a sessões comemorativas (aniversário da entidade, por exemplo) ressalvam a possibilidade de convocá-la para dia não útil, normalmente, o domingo.

Até que ponto a frequência de assembleias resolvia as carências de sociabilidade eventualmente decorrentes do crescimento da entidade? Não temos dados que nos permitam avaliar o crescimento do número de associados à Sociedade de Beneficência Porto-Alegrense, mas o gráfico 1 revela que o número de participantes, nas assembleias gerais da entidade, é semelhante no final das década de 1850 e 1860. Inventariamos as assembleias gerais (exclusive as sem quorum), entre março de 1857 e março de 1860 e entre março de 1867 e março de 1870, e verificamos que havia uma assembleia, em média, a cada mês e meio. No entanto, a diferença entre os dois períodos não está no número de assembleias ocorridas, mas no de frustradas. Nos primeiros três anos, houve dezenove assembleias e apenas uma reunião sem quorum e, no outro triênio, houve vinte e duas sessões de assembleias contra dezenove reuniões sem quorum, uma delas porque faltara número mínimo de membros da diretoria. Retomando os demais números do gráfico 1, podemos afirmar que a frequência de convocação das assembleias pode, quando muito, consolidar a

\footnotetext{
38 TEIXEIRA, Amélia Rosa Sá Barreto. A forma organizativa de auxílios mútuos: contestação ou
} adaptação. Rio de Janeiro: IUPERJ, (Dissertação), 1982 pp. 30-34. 
frequência às assembleias, isto é, manter em contato os associados cujo interesse é "bem compreendido".

Não obstante, existem outros meios de manter o contato do associado com os interesses espirituais do grupo dirigente. Um deles é a publicação de jornais, mas esses também se ressentem de dois tipos de problemas. O primeiro deles é o custo, considerado elevado em associações cujo esforço principal é a satisfação de interesses materiais, tal como ocorre em três mutuais de caixeiros das cidades de Pelotas, de Porto Alegre e de Quaraí. O outro tipo de problema envolve a relação que os jornais mantinham exatamente com as instâncias decisórias das mutuais. Na verdade, alguns jornais estreitamente vinculados a mutuais não eram, institucionalmente, ligados a elas, situação que poderia causar atritos entre as diretorias de sociedades de socorros mútuos e os redatores de jornais.

O mesmo jornal poderia ter textos muito diferentes. Existiam os de caráter administrativo, que podiam conter a justificativa de um sócio, que "[alegava] que a espinhosa vida do mar o impossibilitava de desempenhar satisfatoriamente a missão", para não exercer um cargo na comissão de sindicância. Como outros os membros também pertenciam à mesma profissão, a justificativa foi recusada. Há motivos para crermos que essa fosse uma das ocupações sobre as quais uma mutual de Florianópolis dirigia interesse, inclusive para crescer, quando verificamos a existência de um artigo que louva sem, contudo, convidar para se associarem, "todos os que exercem a profissão marítima, considerada como arte". Como demonstra Leuchtenberger, nem $10 \%$ da associação era composta de marítimos e de estivadores. No mesmo jornal houve, ainda, um "protesto solene" contra um juiz que reclamava da composição da lista de jurados "porque só se qualificaram mendigos e operários". 0 jornal protesta contra a declaração, pois "Sim! Os operários podem ser juízes, porque podem ser mais independentes que os funcionários públicos! [...] porque são homens do trabalho!" ${ }^{39}$ Cada um desses textos dirigia-se, prioritariamente, a diferentes públicos. O primeiro era, claramente, dirigido aos sócios; o segundo, aos associáveis, e o terceiro, ao público em geral. Contudo, há motivos para crermos que mesmo os dois últimos também eram dirigidos aos sócios da mutual, que poderiam sentir-se valorizados com menções a sua ocupação ou com a injustiça do desprestígio. Essa valorização poderia redundar na lealdade para com a associação. Ousaríamos afirmar que os critérios de fechamento de uma mutual estavam relacionados ao tipo de retórica aí desenvolvida, no sentido de que, quando existiram fechamentos, foi

\footnotetext{
${ }^{39}$ O Operário. Florianópolis, 15 fev. 1901, p. 1; 15 out. 1900, p. $1 ; 2$ abr. 1901, p. [?] (BPESC). e LEUCHTENBERGER, Rafaela. “O Lábaro..." op. cit., p. 90.
} 
possível demarcar com maior precisão o tipo de texto adequado para cada público. Certamente, não era para o público interno que a mutual italiana de Alegrete publicou um anúncio, em português, no jornal local, sobre sua participação nas comemorações do centenário da independência do Brasil ${ }^{40}$. Uma mutual aberta tendia a ser lacônica, ao passo que mutuais com algum tipo de fechamento precisavam, pelo menos, na definição dos critérios de fechamento, presentes nos estatutos, construir escalas de valores que justificassem esse fechamento.

Tememos explicações funcionais, mas elas podem ser adequadas para sociedades de socorros mútuos que persistem no tempo enquanto incorporam (ou não) novos associados. Dizer que a função do fechamento é permitir discursos é, certamente, um exagero que pode ser, no máximo, parcialmente verdadeiro. Contudo, todas as mutuais agem, de algum modo, na distribuição de prestígio social. A adoção de fechamentos relacionados à ocupação ou ao grupo étnico atende a requisitos que combinam interesses materiais e espirituais, quando são capazes de securitizar grupos carentes de prestígio preliminar à associação, mas que estão do lado de dentro do fechamento. Assim, é interessante constatar que, enquanto algumas mutuais de negros de Pelotas relacionam seu fechamento ao trabalho, as de Porto Alegre, relacionam-no à nacionalidade. Embora nenhuma das entidades compusesse-se, exclusivamente, de negros, há referências, na bibliografia, sobre o vínculo entre as mutuais e a população negra das duas cidades ${ }^{41}$. Não estamos, com isso, afirmando que a adscrição de uma determinada mutual a um certo critério de fechamento obedece a um sofisticado cálculo estratégico acerca do rol de grupos prestigiosos e disponíveis para o crescimento da associação. Sustentamos que, mesmo que o fechamento preliminarmente adotado provenha do senso comum, sua eficiência revela-se, de um lado, no crescimento efetivo da mutual e, de outro, na possibilidade de produzir atos retóricos de atribuição de prestígio a um rol menor do que o das adscrições disponíveis. Não somos capazes, com isso, de explicar, precisamente, por que as mutuais de negros de Pelotas apostaram, preliminarmente, em um tipo de fechamento, enquanto as de Porto Alegre em outro, mas, sim, de demonstrar o porquê a única mutual que, explicitamente, assume a restrição de filiação aos brancos, a Filhos do Trabalho, de Rio Grande, não chegou a completar três anos de existência. Talvez, a entidade fosse incapaz de produzir discursos de prestígio dos grupos negros de modo eficaz. É como se o veículo privilegiado de tais discursos, no Rio Grande do

\footnotetext{
${ }^{40}$ Gazeta de Alegrete. Alegrete, 7 set. 1922, p. 24 (AHMPA).

${ }^{41}$ LONER, Beatriz Ana. Construção de classe: operários de Pelotas e Rio Grande (1888-1930). Pelotas: Editora UFPel/Unitrabalho, 2001.; MÜLLER, Liane Susan. "As contas do meu rosário são balas de artilharia" - Irmandade, jornal e sociedades negras em Porto Alegre 1889-1920. Porto Alegre: IFCH, PUCRS, (Dissertação, mestrado em história), 1999.
} 
Sul, fosse a imprensa, que não dependia tanto da fidelidade do aporte regular de dinheiro de seus leitores, como dependiam as mutuais de seus sócios. Ademais, a explicação que incorpora os limites econômicos das mutuais para a satisfação de interesses espirituais é consistente tanto em relação ao laconismo das mutuais abertas, quanto com a inexistência de maiores fechamentos nas outras entidades ao longo do tempo, quando o que ocorre é, precisamente, o contrário, isto é, as entidades mais perenes ampliam o rol dos associáveis.

A precariedade de uma generalização decorre das poucas fontes consultadas, mas nos sentimos em condições de afirmar que o tempo de funcionamento de uma mutual é acompanhado da racionalização de seus procedimentos, racionalização que pode ser vista na burocratização da relação com associados, na sofisticação dos atos retóricos (quando a mutual é capaz de definir, com maior precisão, a quem são dirigidos os discursos e os argumentos, que expressam escalas de valores) e na formalização dos procedimentos administrativos. É como se a experiência de produção de discursos de atribuição de prestígio se acumulasse de forma a evitar que a satisfação de interesses espirituais ressinta-se com a ampliação dos associáveis.

A formalização dos procedimentos administrativos, porém, suporia também a separação entre cargo e pessoa, fenômeno mais difícil de ocorrer quando as mutuais incorporam também interesses espirituais a suas finalidades. Assim como as mutuais abertas produzem menos atos retóricos, seus dirigentes, aparentemente, também não acumulam muito prestígio em outros espaços. Já as entidades com algum tipo de fechamento acabam por atribuir a seus dirigentes parte do prestígio construído pelos e/ou atribuído aos associados, e prestígio não é algo separável da pessoa. Muitos dos casos de disputa eleitoral ocorridos (alguns já mencionados), na Sociedade de Beneficência Porto-Alegrense, acabaram revestindo-se de um caráter passional inconsistente com a separação entre o cargo e a pessoa. Não é diferente a relação de Antônio Guedes Coutinho com a Sociedade União Operária, de Rio Grande. Mesmo abrindo mão da leitura da biografia do personagem, que amiúde trata de eventos nos quais inexiste a separação, um caso reportado, em setembro de 1897, é exemplar. Em meio ao debate de se a entidade deveria ou não pedir subvenção ao governo municipal, um sócio declarou "que tem honra na cara [...], que não era como o companheiro Coutinho que tinha dado sua palavra de honra de não sentar-se mais à mesa e que entretanto lá estava!". Calorosas discussões seguiram-se e Coutinho decidiu retirar-se da mesa, por se julgar "ofendido [...], visto que alguém o julgava capaz de abusar do lugar para fazer vencer as suas opiniões". Os favoráveis a Coutinho pediram e insistiram para que ele voltasse, mas ele se recusava. Até que um deles "apelou enfim para os deveres de socialista que obrigam o companheiro Coutinho a 
sofrer muitas desilusões, e pediu à assembléia que com uma salva de palmas manifestasse o seu desejo de que o companheiro Coutinho reassumisse a presidência", no que foi atendido em ambos pedidos por ambos públicos ${ }^{42}$. Não nos deixemos enganar pela "desilusão" do socialista, porque esta, como outras disputas de honra, tão comuns, no movimento operário do período, evidenciam que a "honra" não é um tesouro acumulado, mas um capital inexistente ou sem sentido enquanto não é posto em ação ${ }^{43}$. É por isso que afirmava a necessidade de algum tipo de fechamento para a construção da honra, porque, sem ele, não há disputa que dê um sentido, suficientemente, forte para que o associado típico se perceba compartilhando também de interesses espirituais com a mutual.

Não devemos pensar, contudo, que as disputas no interior das sociedades de socorros mútuos sejam de pouca relevância quando envolvem, na maior parte das vezes, apenas interesses espirituais. Nem os casos da Sociedade de Beneficência PortoAlegrense, nem o caso mencionado da Sociedade União Operária, talvez, por serem disputas crônicas, tiveram um desfecho tão drástico quanto o final do caso que ocorreu na Vittorio Emanuele, de Porto Alegre, em 1914. Esse caso demonstra, com clareza, a ausência de separação entre o cargo e a pessoa e o peso da honra nas relações intersubjetivas. Carmine Grimaldi e Pedro Mattiola, ambos membros da diretoria da mutual, divergiam acerca do aluguel, para bailes, da sede de uma associação negra. A despeito das desavenças que já vinham ocorrendo entre ambos que tinham discutido, em público, quando Mattiola foi ao açougue de Grimaldi, no Mercado Público, para tomar satisfações -, o ápice da disputa seriam as eleições na mutual, quando cada contendor apoiava uma chapa. Apurados os resultados, houve dúvidas sobre o que fazer com os votos em branco. A comissão eleitoral decidiu incluílos entre os votos da chapa de oposição, que obtivera maioria, entre outros motivos, porque as cédulas "somadas a qualquer das frações, nada alterava[m] o resultado já conhecido". Os contendores, mais uma vez, assumiram posições diferentes sobre essa decisão, sobretudo porque Grimaldi, que era o presidente da entidade, argumentava que os votos em branco deveriam ser computados como favoráveis à chapa oficial, uma vez que indicariam o desejo do associado de deixar a situação como estava. A tensão do processo eleitoral levou à necessidade de apartar Grimaldi e Mattiolla e a pedidos de suspensão da sessão, o que não ocorreu. A posição de Grimaldi foi derrotada pela eleição e pela comissão eleitoral. Não havia dúvida sobre o que

\footnotetext{
${ }^{42}$ SCHMIDT, Benito Bisso. Um socialista no Rio Grande do Sul: Antônio Guedes Coutinho (1868-1945). Porto Alegre: Ed. Universidade/UFRGS, 2000.; Echo Operário. Rio Grande, 19 set. 1897, p. 2 (NPH).

${ }^{43}$ Trabalhamos o tema, com mais vagar, em: SILVA Jr., Adhemar Lourenço da. O herói no movimento operário. In: LOIVA, Otero Félix, ELMIR, Cláudio Pereira (Orgs.). Mitos e heróis: construção de imaginários. Porto Alegre: Ed. da Universidade-UFRGS, 1998, cf., especificamente, pp. 111-139.
} 
desejava a maioria dos associados com direitos políticos, mas Grimaldi tinha dúvidas, sim, sobre quantos apoiavam a sua posição e não permitiu que o ápice da disputa eleitoral fosse também o ápice da disputa pessoal. Esperou o vencedor na saída da mutual e usou de seus conhecimentos técnico-profissionais de açougueiro para aplicar uma facada de sete cm, "por onde saíam os intestinos de Mattiola"44.

À guisa de conclusão, podemos afirmar que as mutuais atendem a interesses materiais, pertencendo à esfera econômica e que podem atender a interesses políticos e a interesses espirituais de prestígio, quando, então, também pertenceriam às esferas políticas e sociais. No entanto, a forma como se relacionam essas esferas não é generalizável, porque sequer podem ser pressupostas como estáveis ao longo do tempo nas associações.

Recebido em 19 de junho de 2010.

Aceito para publicação em 30 de julho de 2010.

${ }^{44}$ Processo-crime (Júri). Porto Alegre, n. 5203.1, Maço 294, Estante 29, 1915 (APERGS). Os trechos citados textualmente estão nas fls. 6 e 32. 